\title{
Studies on some heavy metal contents of ximenia americana and sclerocarya birrea wild fruit from North-Eastern Nigeria.
}

\author{
G.A Maspalma $^{1}{ }^{*}$, U.A Maryam ${ }^{1}$, M.B. Hamid ${ }^{2}$, K.S Hamman ${ }^{3}$ and S.P Artimas ${ }^{1}$. \\ ${ }^{1}$ Chemistry Unit, Department of Science Laboratory Technology, Adamawa State Polytechnic Yola, \\ Adamawa State, Nigeria. \\ ${ }^{2}$ Biochemistry Unit, Department of Science Laboratory Technology, Adamawa State Polytechnic Yola, \\ Adamawa State, Nigeria. \\ ${ }^{3}$ Biology Unit, Department of Science Laboratory Technology, Adamawa State Polytechnic Yola, \\ Adamawa State, Nigeria. \\ *Corresponding author:agoddypalma@gmail.com +2347035410631 \\ Received 15 January 2021; accepted 08 March 2021, published online 30 March 2021
}

\begin{abstract}
Fruits play important role in providing the individuals daily dietary needs from vitamins, iron, and some metals that are needed in the body as dietary supplement or as an important element that form some hormones or enzymes in small concentrations, if exists in high concentrations become toxic with side effects. The presence of heavy metals such as of $\mathrm{Fe}, \mathrm{Cd}, \mathrm{Pb}, \mathrm{Cr}, \mathrm{Mn}, \mathrm{Ni}, \mathrm{Co}$, and $\mathrm{Zn}$ in Ximenia americana and sclerocarya birrea wild fruits were determined using standard methods such as AAS. Results obtained from this study revealed that the concentration of the metals in sclerocarya birrea was Iron, $(8.83 \pm 0.10)$ Cadmium $(0.01 \pm 0.00)$ Lead $(0.04 \pm 0.02)$ Chromium $(0.19 \pm 0.10)$ Manganese $(4.27 \pm$ $0.20)$ Nickel $(0.21 \pm 0.10)$ Cobalt $(0.09 \pm 0.01)$ and Zinc $(2.96 \pm 0.02) \mathrm{mg} / \mathrm{g}$. On the other hand, Ximenia americana content was Iron, $(6.37 \pm 0.10)$ Cadmium $(0.02 \pm 0.01)$ Lead $(0.01 \pm 0.00)$ Chromium $(0.24 \pm 0.01)$ Manganese $(2.50 \pm 0.10)$ Nickel $(0.29 \pm 0.10)$ Cobalt $(0.17 \pm 0.00)$ and Zinc $(2.31 \pm 0.06)$ $\mathrm{mg} / \mathrm{g}$ respectively. Highest concentration of Iron was recorded as $(8.83 \pm 0.10) \mathrm{mg} / \mathrm{g}$ in the sclerocarya birrea sample analyzed, while Lead and Cadmium were found to be the least with concentration of $(0.01$ $\pm 0.00) \mathrm{mg} / \mathrm{g}$ in both samples. Their concentrations are within the maximum allowable concentration (MAC) set by FAO/WHO. The findings of this study reveal that there are no health risks associated with the consumption of heavy metals through the intake of these two fruits.
\end{abstract}

Keywords: Heavy metals, Ximenia americana, Sclerocarya birrea, Wild plant, Fruits

\section{Introduction}

Wild fruits have helped to provide a steady supply of fruits during the dry season when cultivated fruits are scarce and expensive for low income earners that traditionally have large family [27]. Millions of people in many developing countries do not have enough food to meet their daily requirements and most people are deficient in one or more micronutrients [13].

Food safety is a major public health concern worldwide. Because of the increasing risk of contamination of food by pesticides, heavy metals, and/or toxins, the food safety issues have attracted the attention of research recently [10]. Contamination with heavy metals is important, particularly in agricultural production systems and human health. Factors influencing the concentration of heavy metals in plants include climate, environmental pollution, nature of the soil on which the plant is grown, and the degree of maturity of the plant at the time of harvesting [25] [26].

Trace metals have been found to play both positive and negative roles in human health. They can be classified as toxic (arsenic, cadmium, lead, mercury, nickel, etc.), probably essential (vanadium), and essential (copper, zinc, iron, manganese, selenium, and cobalt) metals. However, toxic effects of the last two classes of metals have also been identified when the intake is excessively high. Heavy metals have damaging effects on humans and animals, because of their non -biodegradable nature, long biological halflives, and potential to accumulate in different body parts as there is inadequate mechanism for their elimination from the body [19].

Ximenia Americana "Wild olive or Plum" in English or locally called "Tsada" in Hausa, "Chabbuli" in Fulani and "Igo" in Yoruba, is a medicinal plant that is bushy and spiny shrub, 4 - 
$5 \mathrm{~m}$ high with an open crown. The fruits are green but turn golden yellow or red when ripe. The fruit when eaten is refreshing and has an almond acid taste. The plant is used in traditional medicine for treatment of malaria, fever, leprotic ulcers and skin infections of mixed origin in Northern parts of Nigeria [23]. The medicinal uses of $X$. Americana include treatment of fever, stiffness, onchocerciasis, sore throat, asthma and headaches. The roots are used for treating abdominal pains, dysentery, inflamed joints and mouth ulcers [2].

Sclerocarya birrea "Marula" is a savannah tree belonging to the order, Sapindales, family Anacardiacaea, deciduous tree; it is up to 15 metre high with well-formed light green grown. It is commonly known as ale odan in Yoruba, eedi in Fulani and "Nunu" or "Loda" or "Daniya" among the Hausa speaking community of West Africa [14]. The mature fruits $(3.5 \mathrm{~cm}$ in diameter) of Sclerocarya birrea are green but change to yellow ripens. The fruit contain a large stone and a white clinging flesh from which the juice can be extracted. Fruit when eaten in large amount by human or animal may be intoxicated [21]. locally the tree requires sandy or an alluvial soil, its propagation is with seed or cutting. The fruit are used in the liqueur amarula. Different parts of the plant (stems-bark, roots and leaves) are used in curing various human ailments such as abdominal cramps, abscesses, arthritis, backache, body pains, boils, carbuncles, constipation, cough, diabetes mellitus, diarrhea, dysentery, epilepsy, fevers, headaches, hypertension, infertility, malaria, proctitis, stomach ailments, sore eyes, schistosomiasis, sores, toothache, and certain other bacterial infections [17].

Adamawa state in North-Eastern Nigeria is characterized largely by these conditions, favoring the growth of both trees, which are found in great abundance. They produced a large number of edible fruits seasonally that are being sold openly in the local markets. The fruits attract men and animals to consume them, and so were among the original foods of the human race, particularly because they are mostly edible raw. This paper is a report of the work conducted to investigate the concentration levels of some heavy metals contaminants in the fruits of Ximenia americana and Sclerocarya birrea plants. At present there is limited information on heavy metal contents in highly consumed fruits in (North-East). It is hope that the useful information obtained will help in order to establish them as potential raw material in making fruit juice, and also to identify the wild edible plant resources among the rural dwellers.

\section{Materials and methods Precaution}

To ensure reliability of the results, samples were carefully handled to avoid contamination. All glassware used was soaked in $1 \mathrm{M}$ nitric acid for $48 \mathrm{~h}$ and rinsed with pure water. The reagent (Nitric acid) was of analytical grade.

\section{Description of the Study Area}

The study area is a settlement known as Pella a mountainous community in Hong Local Government Area of Adamawa State, North eastern Nigeria. Pella village lies within longitudes $12^{\circ} 50^{\prime} \mathrm{E}$ to $13^{\circ} 00^{\prime} \mathrm{E}$ and latitude $10^{\circ} 05^{\prime} \mathrm{N}$ to $10^{\circ} 22^{\prime} \mathrm{N}$. The area falls within Hong Local Government Area of Adamawa State, North-eastern Nigeria and is accessible through Gombi- Mubi road, Hong- Garaha road and Hong-Gaya road. Hong and environs are drained by Kilanye and Shashau Rivers [4]. The area is characterized by dry season (October to March) and wet season (April to September). The area falls within the Sudan Savannah vegetation type which consists of shrubs, grasses and trees especially along the river channels [8].

\section{Samples and sampling preparation}

The matured and ripe Ximenia americana and Sclerocarya birrea fruits were collected from farmlands in Pella and Pella Gwaja between the months of May- June, 2012 and were authenticated by a botanist in the Science laboratory technology department, Adamawa State Polytechnic, Yola. Three trees each were randomly selected and the fruits collected from different branches of the selected tree, as described in the method of Hassan and Umar [15]. Representative sample was taken using alternate shovel method [1]. The representative samples were thoroughly washed with distilled water and the residual moisture evaporated at room temperature.

\section{Sample digestion}

The sample digestion was carried out according to the method outlined by [16]. $1.2 \mathrm{~g}$ of dried 
powered samples were digested with $5 \mathrm{~cm}^{3}$ of triacid mixture $\left(\mathrm{HNO}_{3}: \mathrm{HClO}_{4}: \mathrm{H}_{2} \mathrm{SO}_{4}: 9: 2: 1\right)$ on a hot plate and filtered by whatman filter paper and made up the volume to $50 \mathrm{~cm}^{3}$ with distilled water.

\section{Preparation of Standards}

Standards solution of chromium, manganese, Iron, cobalt, nickel, zinc, cadmium and lead were prepared using Iron (III) chloride, Manganese (II) chloride, Zinc nitrate, Cadmium chloride, Chromium nitrate, Nickel (II) nitrate, Cobalt (II) nitrate and Lead nitrate salts respectively for the calibration of the instrument. $4.95 \mathrm{~g}$ of $\mathrm{FeSO}_{4} \cdot 7 \mathrm{H}_{2} \mathrm{O}, 1.598 \mathrm{~g}$ of $\mathrm{Pb}\left(\mathrm{NO}_{3}\right)_{2}, \quad 6.50 \mathrm{~g}$ of $\mathrm{Cr}\left(\mathrm{NO}_{3}\right)_{2} .9 \mathrm{H}_{2} \mathrm{O}, 6.8 \mathrm{~g}$ of $\mathrm{CdSO}_{4} .8 \mathrm{H}_{2} \mathrm{O}, 3.076 \mathrm{~g}$ of $\mathrm{MnSO}_{4} .9 \mathrm{H}_{2} \mathrm{O}, 4.49 \mathrm{~g}$ of $\mathrm{Zn}\left(\mathrm{NO}_{3}\right)_{2}$ were weighed separately using Analytical weighing balance and dissolved in a $1000 \mathrm{~cm}^{3}$ volumetric flask and made up to mark with distilled water [18].

\section{Analysis of the samples}

$\%$ Recovery $=$ Concentration obtained $(\mathrm{mg} / \mathrm{L})-$ Concentration added $(\mathrm{mg} / \mathrm{g})$
Metal concentrations were determined on a Buck scientific model 210VGP Atomic Absorption Spectrometer (AAS) equipped with a background correction. The result of each sample represents an average of three replicate readings. A calibration curve of absorbance against concentrations of each element under investigation was constructed and finally the concentration of each element was determined from the calibration curve of its standards by interpolation.

Determination of the Efficiency of the Method To determine the efficiency of the method, a recovery study was carried out. This was done by spiking a known concentration $(0.5 \mathrm{mg} / \mathrm{g})$ of one of the metals of interest into one of the fruit samples prior to digestion and the sample was subjected to all the pretreatment step as other samples and analyzed using AS after pretreatment and digestion. The percentage recovery was calculated using the following expression.

Concentration added (mg /L)

\section{Results and discussion}

In this study, concentrations of $\mathrm{Fe}, \mathrm{Cd}, \mathrm{Pb}, \mathrm{Cr}$, $\mathrm{Mn}, \mathrm{Ni}, \mathrm{Co}$, and $\mathrm{Zn}(\mathrm{mg} / \mathrm{g})$ were determined in the two fruits samples. The levels of heavy metals found in the analyzed fruit samples are listed in Tables 1. All metal concentrations were expressed in dry weight basis.

Iron $(\mathrm{Fe})$ is important in the diet especially for pregnant and nursing mother as well as infants. It is also needed by the convalescent and elderly to reduce cases of disease associated with deficiency of Iron such as anemia [10]. The result obtained shows that sclerocarya birrea contains the highest concentration of the Iron content. The concentration of Iron $(\mathrm{Fe})$ was $8.83 \pm 0.15 \mathrm{mg} / \mathrm{g}$ and $6.37 \pm 0.16 \mathrm{mg} / \mathrm{g}$ in Sclerocarya birrea and Ximenia americana respectively.

Zinc is important for nerve function and male fertility.t is important for normal sexual development of testes and ovaries. It is also essential for reproduction [3]. Healthy functioning of the heart and normal growth [11]. Regular consumption of these fruits may assist in preventing the adverse effect of Zinc deficiency which result in retarded growth and delayed sexual maturation because of its role in nucleic acid metabolism and protein synthesis [6]. The concentration of Zinc (Zn) was $2.96 \pm 1.00 \mathrm{mg} / \mathrm{g}$ and $1.31 \pm 0.06 \mathrm{mg} / \mathrm{g}$ in Sclerocarya birrea and Ximenia americana respectively.

Manganese was found to be more concentrated in Ximenia Americana $(4.27 \pm 0.20 \mathrm{mg} / \mathrm{g})$ and lower in Sclerocarya birrea $(2.50 \pm 0.10 \mathrm{mg} / \mathrm{g})$. The concentration of $\mathrm{Mn}$ in these fruits is not up to the extent that, are likely to cause harm to the individuals consuming them. But rather help them in preventing adverse effects of dietary deficiencies of manganese on the central nervous systems and skeletal anomalies among children [6]. According to [18], when people do not live up to the recommended daily allowance their health decrease, but when the uptake is too high health problems also occur. The recommended daily allowance for $\mathrm{Mn}$ is 2.5 to $5.0 \mathrm{mg}$ [12].

Cobalt is usually found in the environment combined with other elements such as oxygen, sulfur, and arsenic. Small amounts of these chemical compounds can be found in rocks, soil, plants, and animals. Deficiency produces cardiomyopathy, congestive cardiac failure, pericardial effusion, polycythemia, and thyroid enlargement [5]. Cobalt has both beneficial and 
harmful effects on human health. It also increases RBC production in healthy people, but only at very high exposure levels. Deficiency of cobalt also leads to fatigue, digestive disorders, and neuromuscular problems. As cobalt's deficiency leads to decreased availability of B12, there is an increase of many symptoms and problems related to B12 deficiency, particularly pernicious anemia, and nerve damage [24]. In this study the concentration of Co was $0.09 \pm 0.01$ $\mathrm{mg} / \mathrm{g}$ and $0.17 \pm 0.00 \mathrm{mg} / \mathrm{g}$ in sclerocary abirrea and Ximenia americana respectively

\section{Table 1: Statistics summary for the concentration of heavy metals in the Wild Fruits}

\section{Ximenia Americana}

\begin{tabular}{llll} 
Metals & Mean Std. & Mean Std. & MAC $(\mathrm{mg} / \mathrm{g})$ \\
\hline $\mathbf{C d}$ & $0.02 \pm 0.01$ & $0.01 \pm 0.00$ & 0.05 \\
$\mathbf{C o}$ & $0.17 \pm 0.00$ & $0.09 \pm 0.01$ & - \\
$\mathbf{C r}$ & $0.24 \pm 0.010$ & $19 \pm 0.10$ & 1.0 \\
$\mathbf{F e}$ & $6.37 \pm 0.1$ & $68.83 \pm 0.15$ & - \\
$\mathbf{M n}$ & $2.50 \pm 0.10$ & $4.27 \pm 0.20$ & - \\
$\mathbf{F e}$ & $6.37 \pm 0.1$ & $68.83 \pm 0.15$ & 0.8 \\
$\mathbf{N i}$ & $0.29 \pm 0.10$ & $0.21 \pm 0.10$ & \\
& & & 0.1 \\
$\mathbf{P b}$ & $0.01 \pm 0.00$ & $0.04 \pm 0.02$ & - \\
$\mathbf{Z n}$ & $2.31 \pm 0.06$ & $2.96 \pm 1.02$ & \\
\hline
\end{tabular}

MAC = Maximum allowable concentration [13].

Lead is a toxic substance that pose a variety of danger for humans, High level of lead in the body can cause lasting problem with growth and development, these can affect behavior, hearing and learning and can slow child's growth, it can damage the brain kidney, nervous system and stomach of both children and adults [22]. In the fruit samples, lead $(\mathrm{Pb})$ content was found to be the highest in sclerocarya birrea $(0.04 \pm 0.02$ $\mathrm{mg} / \mathrm{g})$ and lowest in Ximenia americana $(0.01 \pm$ $0.00 \mathrm{mg} / \mathrm{g}$ ) (Table 1). The concentrations of lead were found not to exceed the maximum allowable concentration of $0.1 \mathrm{mg} / \mathrm{g}$ [12].

The need of chromium is for biosynthesis of glucose tolerance factor. The deficiency causes impairment of glucose tolerance while toxicity results in renal failure, dermatitis, and pulmonary cancer. Chromium deficiency is difficult to document because of the very low levels present in blood, while tissue levels are 10 times higher. Welding in stainless steel is associated with an increased risk of cancer of larynx and pharynx due to exposure to hexavalent chromium [7]. In the fruit samples, chromium $(\mathrm{Cr})$ content was found to be $(0.24 \pm 0.01 \mathrm{mg} / \mathrm{g})$ in Ximenia Americana and
$(0.19 \pm \quad 0.10 \mathrm{mg} / \mathrm{g})$ in sclerocarya birrea respectively (Table 1). The concentrations of Chromium in the two fruit samples were below the maximum allowable concentration of $1.0 \mathrm{mg}$ [12]. Nickel plays some important role in biological systems such as in enzyme activity in hormonal control and also in RNA, DNA, and protein structure or function [9]. Toxicity of nickel has the following consequences: higher chances of development of lung cancer, nose cancer, larynx cancer and prostate cancer, sickness and dizziness after exposure to nickel gas, lung embolism, respiratory failure, birth defects, asthma, chronic bronchitis and allergic reactions. The levels of nickel $(\mathrm{Ni})$ in the fruit samples were found in Ximenia americana $(0.29 \pm 0.10 \mathrm{mg} / \mathrm{g})$ and sclerocarya birrea $(0.21 \pm 0.10 \mathrm{mg} / \mathrm{g})$, respectively (Table 1). Ni concentrations in all the two fruit samples were found below the maximum permissible value.

Cadmium is a toxic and carcinogenic element [28]. Due to the high toxicity of lead and cadmium, it is of public health interest that these metals are quantified in beverages and foodstuffs. For instance, cadmium intake in relatively high 
amounts can be detrimental to human health. Over a long period of intake, cadmium may accumulate in the kidney and liver because of its long biological half-life and may lead to kidney damage [20]. The cadmium (Cd) level in fruit samples was found in Ximenia americana $(0.02 \pm 0.01 \mathrm{mg} / \mathrm{g})$ and sclerocarya birrea $(0.01 \pm 0.00 \mathrm{mg} / \mathrm{g})$, respectively

\section{Conclusion and Recommendation}

Trace elements are very important for cell functions at biological, chemical and molecular levels. These elements mediate vital biochemical reactions by acting as cofactors for many enzymes, as well as act as centers for stabilizing structures of enzymes and proteins. This study reported the concentrations of some trace elements in the two selected Wild fruits. The findings have indicated that the wild fruits studied could make significant contribution to the recommended dietary allowances for the trace elements. There is need to investigate the proximate composition of these fruits in order to have a complete picture of their nutritional value.

\section{References}

1. W. Alan (1996): Soil and the environment: An introduction, Cambridge University press

2. M. Arbonnier (2004): Trees, shrubs, and lianas of West Africa dry zones, Margret publisher, GRAD, GMBH MNHN (2) Pp 141-145.

3. P.B Anyoola, A. Adeyeye and O.O Onawumi (2010): Trace Element and Major Evaluation of Spondiasmombin, Vernonia Anygdalina and Momordica Charantia Leaves, Pakistan Journal of Nutrition 9(8): 755-758

4.N.E Bassey, S.S Dada and O.A, Omitigun, (2006): Preliminary structural study of satellite imagery over basement rocks of northeast Nigeria and northern Cameroon; Journal of Mining and Geology 42(1), 73-77.

5. D.G, Barceloux (1999): Cobalt. J Toxicol Clin Toxicol 37:201- 6

6. J.T. Barminas, M, Charles and D. Emmanuel (1998): Mineral Composition of Nonconventional
Leafy Vegetables, Plant Foods for Human Nutrition 53: 29-36

7. M. Costa and C.B. Klein. (2006): Toxicity and carcinogenicity of chromium compounds in humans. Crit. Rev Toxicol. 36:155-63

8. S.S. Dada. (2006): Proterozoic Evolution of Nigeria. In: Oshi O (ed) The basement complex of Nigeria and its mineral resources (A Tribute to Prof. M. A. O. Rahaman). Akin Jinad and Co. Ibadan, pp 29-44.

9. K.K Das, S.N Das and S.A Dhundasi (2008): Nickel, its adverse health effects and oxidative stress, Indian J Med Res 128. pp 412-425.

10. J.P.F D'Mello. (2003): Food Safety, Contamination and Toxins, CABI publishing, Wallingford, Oxon, UK, Cambridge, MA, P.480.

11. K. Elizabeth. (1994): Immense Help from Nature's Workshop. First Ed. Elikaf Health Services Ltd., pp: 207-209.

12. FAO/WHO (Food and Agricultural Organization /World Health Organization) (2002): Report of a Joint FAO/WHO Expert Consultation Bankok, Thailand. expert consultation on human vitamin and mineral requirements. pp. 223-229.

13. FAO (Food and Agricultural Organization of the United Nations) (2004): The state of Insecurity in the World. Monitoring the Progress Towards the World Food Summit 2nd Millennium Developmental Goals. Rome: F. A. O, 2004, pp 51

14. R.S. Glew, D.J Vanderjagt, Y.S Huang. and L.T Chuang (2004): Nutritional analysis of the edible pit of Sclerocarya birrea in the Republic of Niger. Journal of Food Composition and Analysis 17: 99- 111 .

15. I.G. Hassan and K.J. Umar (2004): Proximate and mineral compositions of seeds and pulp of Parkia biglobosa. Nigerian Journal of Basic and Applied Sciences (13): 15-27.

16. I.G. Hassan, M.U. Muhammad. K.J. Umar, and A.M Sokoto. (2008): Comparative Study on the Proximate and Mineral Contents of the Seeds and Pulp of Sugar Apple (Annona squamosa). 
Nigerian Journal of Basic and Applied Sciences.16(2):174-177

17.P.A. Isa, H. Louis, A. J. Innocent and O. Oyebanji (2017): Evaluation of Heavy Metals Concentration in Selected Medicinal Plants (Sterculia setigera Del. and Sclerocarya birrea (A. rich.) Hochst) Collected from Bwabul Spring, Bambuka and Jalingo Low-lands, Taraba State. Environ Anal Chem. 4:4

18.F. Itanna, (2002): Metals in Leafy Vegetables Grown in Addis-ababa and Toxicology Implications. Ethiopian Journal of Health Development. 16: 295-302

19. L Jarup., (2003): Hazards of heavy metals contamination. Br. Med. Bull. 68, 167-182.

20. J.M.U. Maduabuchı. C.N Nzegwu. E.O, Adıgba, R.U Aloke., C.N Ezomıke, C.E Okocha. E. Ob1 and O.E Orisakwe (2006): Lead and cadmium exposures from canned and non-canned beverages in Nigeria: A public health concern. Science Total of Environment,366: 621-626.

21.A.A Mariod, A.O Ali. S.A Ethussien and I.H. Hussien., (2008): Quality of protein and product based on sclerocarya birrea (Marula). Department of food science and technology, University of GezraMedani. Sudan.

22. G. Maspalma, N, Musa and B. Mohammed (2018): Assessment of Physicochemical Quality of some commercially packaged fruit juice sold in Yola metropolis, Adamawa State, Nigeria. ADSUJSR 6 (2) 263-268.

23.D.S Ogunleye. and S.F Ibitoye. (2003): Studies of antimicrobial activity and chemical constituent of Ximenia Americana, Tropic. Journal Pharm. Research. 2(2) 239-24).

24. J. L Paternain, J. L. Domingo and J. Corbella (1988): Developmental toxicity of cobalt in the rat. J Toxicol Environ Health 24:193-200.

25. D. Scott, J.M. Keoghan and B.E. Allan, (1996): Native and low input grasses-a New Zealand high country perspective. NZJ Agric. Res. 39, 499-512
26.D. Voutsa, A Grimanis, and C. Samara, (1996): Trace elements in vegetables grown in an industrial area in relation to soil and air particulate matter. Environ. Pollut. 94, 325e335.

27.H.A. Umaru, R. Adamu, D. Dahiru and M.S Nadro (2007): Levels of Anti Nutritional Factors in Some Wild Edible Fruits of Northern Nigeria. African Journal of Biotechnology, 6 (16): p 19351938.

28.C. Rubio, A. Hardisson, J.I. Reguera, C. Revert, M.A Lafuente and T. Gonzales-Iglesias (2006): Cadmium dietary intake in canary Island, Spain Environ. Research. 100,123 -129 